\title{
Literatura e filosofia em Raul Pompeia
}

\author{
[ Literature and philosophy in Raul Pompeia
}

\section{Marconi Severo ${ }^{\mathrm{x}}$}

Resumo - Ao empregar as técnicas do chiaroscuro e da circularidade interna, Raul Pompeia conseguiu, sob o preço da incompreensão crítica, abordar literariamente suas reflexões filosóficas. Estas, por sua vez, são mais reformistas do que revolucionárias; mais detidas no homem em si, apesar de considerá-lo como essencialmente mau, do que em aportes metafísicos. Recorrendo a fontes originais, procuro destacar que a crítica corriqueiramente recaiu em um grande equívoco ao ressaltar um aspecto mais pessimista e sombrio de Raul Pompeia do que a análise de suas obras permite crer. Palavras-chave • Canções sem metro; filosofia; literatura; Raul Pompeia.

\begin{abstract}
By employing the techniques of chiaroscuro and internal circularity, Raul Pompeia managed, at the cost of critical incomprehension, to literarily address his philosophical reflections. These, in turn, are more reformist than revolutionary; more detained in man himself, despite considering him as essentially bad, than in metaphysical contributions. Using original sources, I try to point out that the critics routinely made a big mistake when highlighting a more pessimistic and gloomy aspect of Raul Pompeia than the analysis of his works allows us to believe. Keywords • Canções sem metro; philosophy; literature; Raul Pompeia.
\end{abstract}

Recebido em 20 de setembro de 2020 Aprovado em I8 de agosto de $202 \mathrm{I}$

SEVERO, Marconi. Literatura e filosofia em Raul Pompeia. Revista do Instituto de Estudos Brasileiros, Brasil, n. 80, p. I04-I27, dez. 202I.

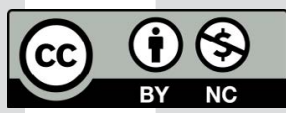

DOI: https://doi.org/Io.II606/issn.23I6-90IX.vIi8opIo4-I27

I Universidade Federal de Santa Maria (UFSM, Santa Maria, RS, Brasil). 
Não quero mal às ficções, amo-as, acredito nelas, acho-as preferíveis às realidades; nem por isso deixo de filosofar sobre o destino das coisas tangíveis em comparação com as imaginárias. Grande sabedoria é inventar um pássaro sem asas, descrevê-lo, fazê-lo ver a todos, e acabar acreditando que não há pássaros com asas... (ASSIS, I894)

Machado de Assis soube precisar perfeitamente bem, com toda a sutileza que lhe é característica, que há, entre a Filosofia e a Literatura, uma relação de complementaridade. A assertiva não deveria causar surpresa, uma vez que ambas "estiveram mais próximas que distantes na longa trajetória intelectual do ocidente", conforme afirma Magalhães (2009, p. 48). Ocorre que tal proximidade não foi capaz de impedir a persistência, mais entre os críticos literários e os estudiosos da filosofia do que propriamente entre os escritores e os filósofos, de um certo exotismo, visível sobretudo quando se pensa no estudo de suas mútuas relações. Mas como pode uma abordagem que vise estabelecer nexos, como dizem os linguistas, entre uma área e outra do conhecimento humano, sendo que ambas fundam-se na "paixão inventiva" que é "tanto do criador literário como do filósofo", conforme asseverou Higino (2OII, p. 74), despertar certa admiração? Para compreender de onde vem esse pensamento, basta nos remontarmos à gênese do pensamento filosófico: para que fosse possível definir e assegurar suas fronteiras em relação à poética, a Filosofia como que se viu obrigada a estabelecer um modo próprio de pensar e se expressar (pensemos, por exemplo, na proximidade entre as obras de Parmênides e Homero, em um primeiro momento, e na posterior diferenciação efetuada por Platão e assegurada por seus sucessores). Essa diferenciação só seria contestada, segundo Nunes (20II), com o advento do romantismo alemão de fins do século XVIII, quando os literatos passaram a incorporar questões filosóficas em suas obras.

Desde então, apesar das diferenciações disciplinares rigidamente asseguradas pelo senso acadêmico, a Literatura e a Filosofia têm assumido uma postura interativa, o que nos permite afirmar que, mesmo como "disciplinas", ambas possuem em comum o fato de que "vivem do enigma que permanece a respeito das relações entre linguagem e mundo", conforme alega Gagnebin (20II, p. I4). Por esse ângulo, como não conceber que existe uma inegável proximidade - mesmo na discordância - entre, 
por exemplo, Sartre e Camus, ou mesmo entre Dostoiévski e Nietzsche, passando por Hesse e a Filosofia Oriental? Como deixa evidente Machado de Assis, também aqui, no Brasil, alguns nomes consagrados às letras transitaram ou fizeram filosofia. É o caso, dentre outros, de Raul d'Ávila Pompeia. Frequentemente lembrado por ser o autor de O Ateneu, e, em menor escala, por sua intensa agitação política nos dois primeiros governos republicanos, Pompeia também deixou registradas inúmeras reflexões filosóficas, sobretudo em Canções sem metro, sua obra-prima. ${ }^{2}$

Todos os estudiosos que se dedicaram com mais afinco ao estudo do seu legado são unânimes ao ressaltar que o escritor acalentou o desenvolvimento de suas canções - publicadas de forma avulsa desde I883 - ao longo de toda a vida. Rodrigo Octávio, também escritor e amigo de Pompeia, chegou mesmo a afirmar (I896, p. III) que dos "seus trabalhos porém, a obra prima, aquela a que ele dedicou mais cuidadoso desvelo e que por certo mais amava, é o belo livro das Canções sem metro", em "cujo lavor o artista trabalhava desde 83 ". Embora Octávio se refira a um livro, a primeira compilação seria publicada somente em I900, portanto postumamente. As canções, diz ele, de início eram "pequeninas", a fim de transmitir "uma impressão apenas, uma simples mancha, como se diz na linguagem dos ateliers", o que explica o porquê de algumas (da primeira parte do livro, intitulada Vibrações) serem subordinadas "cada uma ao sentimento que na imaginação popular corresponde a cada cor do espectro: Verde, esperança; amarelo, desespero; azul, ciúme”. Tomando como verdadeira essa premissa, penso que não seria exagero afirmar que dentre o universo de associações entre cores e sentimentos, prevalece ao longo de Canções sem metro o tema do "verde, esperança": é a esperança, e não o pessimismo, o fator mais recorrente na obra de Raul Pompeia.

Mas, se Pompeia era "sobretudo um artista", conforme se referiu Octávio (I896, p. II2), era-lhe então natural a ideia de ir "além das cores", do que resultou que "outras canções se foram juntando às primitivas, e quando o poeta as tinha prontas, as fez de novo, e sobre elas levou toda a vida a trabalhar até a última noite” (p. III). Essa informação é particularmente relevante: se por um lado Araújo (20I3), Pontes (I934) e Silva (200I, 2003) são unânimes, juntos com Araripe Júnior (I888, I894) e Domício da Gama (I900), ao apontarem para a dedicação com que Raul Pompeia compôs suas Canções sem metro, por outro não deixa de surpreender o fato de que a crítica se atenha predominantemente a $O$ Ateneu - o que deve causar ainda mais espanto quando se sabe que poucas horas antes de se suicidar, Pompeia teria entregado à sua mãe uma versão definitiva, há muito prometida, de suas Canções sem metro.3 João Andréa, editor da primeira compilação, alegou que a publicação do volume lhe foi confiada, de fato, pela mãe do escritor. Essa é a razão pela qual priorizei, ao longo deste texto, a versão original de I900, justamente por entender que ela era aquela que o escritor pretendeu ser a definitiva. Isso não quer dizer, contudo, que seja a mais completa edição das canções, pois muitos poemas em prosa não foram nela incluídos.

Tal supressão textual, que obrigatoriamente precisava ser corrigida para que fosse

2 A dimensão política da obra de Raul Pompeia constitui uma lacuna que está por ser explorada. Sobre o assunto, vale a pena conferir os trabalhos de César Braga-Pinto (2014a, 2014b) e Ana Silva (2002).

3 Conforme o editorial do Jornal Gazeta da Tarde (26/12/1895). 
possível dar sequência à análise hermenêutica aqui proposta, não chegou a constituir um problema, e isso por duas razões: primeiro, porque foi possível contrastá-la com a edição de 20I3, que considero como a melhor e mais completa versão atualmente disponível; segundo, porque a pesquisa junto ao acervo digital da Biblioteca Nacional possibilitou o contato com fontes primárias, o que me permitiu ter acesso à leitura na versão original. ${ }^{4}$ Logo, a opção pela edição de I900 pauta-se, sobretudo, pelo seu valor histórico. Penso que também é válido destacar, em relação a outros escritores, como o próprio Machado de Assis, que o legado literário de Raul Pompeia foi de certa forma minimizado pela crítica. Possivelmente isso tenha a ver com o fato de que uma parte significativa dos estudos sobre Pompeia restringiu-se a elaborar interpretações sobre outras interpretações, isto é, a efetuar análises que, apesar do mérito que possuem, dispensam o cuidado metodológico com as fontes primárias.

Marciano Silva, um dos últimos grandes estudiosos de Pompeia, asseverou que o escritor fluminense figura entre os incompreendidos e injustiçados pela crítica (200I, p. I09). Ao que tudo indica, essa incompreensão deve-se a seu vanguardismo literário e à desenvoltura com a qual Pompeia transitou por diversas correntes literárias. Talvez tenham sido esses aspectos de sua personalidade que levaram seu também amigo Arthur Azevedo, sob o pseudônimo de Eloy, o Herói, a se referir às Canções sem metro como portadoras de uma "carinhosa música". Contudo, um dos primeiros escritores a notar o potencial inventivo de Raul Pompeia foi ninguém menos do que Capistrano de Abreu, que já em crônica de 29 de março de I882 (Pompeia tinha então I8 anos) afirmava o seguinte: "É um espírito ousado; procura sendas não batidas, e às vezes encontra-as; não tem medo da solidão; vai só e tem certeza de chegar".

Para dar uma prova do aspecto filosófico da obra de Raul Pompeia, e isso ainda sem adentrar em suas canções, basta analisarmos rapidamente sua crônica intitulada, sugestivamente, de Cartas ao futuro, publicada postumamente em 27 de dezembro de I897: "descobrir não é criar; inventar é simplesmente harmonizar os elementos e aplicar; o elemento não se inventa; existe", do que decorre que "indagar o modo de ser é indagar o do arranjo". Ora, por acaso não é justamente isso que pretendemos fazer com sua obra, ou seja, indagar, perscrutar, analisar o modo de ser e o arranjo contido em suas Canções sem metro? Penso que há nessa mesma crônica uma frase que resume muito do que foi o seu projeto constitutivo das Canções, qual seja: "O gênio penetra a cavalo nos recônditos dos santuários e estilhaça as lájeas da nave e despedaça os deuses a golpes de análise", embora "ao fim da profanação, ferido e exangue, pela resistência dos guardas invisíveis dos santuários do nada o gênio sucumbe, reconhecendo como D. Quixote que fez a guerra a fantasmas, combatendo visões e sombras". É justamente o que Pompeia fez, pois analisou a fundo, sob o risco da incompreensão, os recônditos da natureza humana; mas ao fazer isso, sai com sua própria alma ferida e, embora nem o gênio escape ao fim do ciclo vital (a morte), sua obra, entretanto, permanece inabalável. Pompeia era o que se pode chamar de visionário. "O gênio", diz ele, "vê melhor o charco, ouve melhor o coaxar das rãs, sente melhor a atmosfera do miasma. Por isso o gênio é sombrio". Constitui uma pena que

4 Agradeço à equipe responsável pela disponibilização do acervo digital da Biblioteca Nacional, cujo material pesquisado foi indispensável para a elaboração do presente texto. 
a crítica, não satisfeita com este sombrio enquanto sinônimo de seriedade, tenha a ele acrescentado um corolário de adjetivos que, para serem aplicados, necessitam deturpar ao absurdo o seu destinatário, do que resulta um uso extremamente duvidoso, embora mais para o adjetivador do que para o adjetivado. ${ }^{5}$

Ao longo deste artigo, portanto, procuro contemplar os seguintes temas: defendo que há na obra de Raul Pompeia antes um apelo à esperança (fator positivo) do que um pessimismo sombrio (fator negativo); argumento também que o que torna Canções sem metro ímpar em meio à sua produção literária é sua concepção filosófica tácita e o seu vanguardismo literário. Não me atenho aqui unicamente ao vanguardismo no gênero do poema em prosa - ou prosa poética, segundo Braga-Pinto (20I4b) -, mas também às suas técnicas composicionais, que são basicamente duas: a circularidade interna e o chiaroscuro. São elas que possibilitam a riqueza filosófica da obra, o "benefício moral da leitura”, como disse certa vez Pompeia. É assim que a filosofia tácita se faz presente, ou seja, por meio das mensagens implícitas, das figuras de linguagem e de estilo, cuidadosamente arregimentadas de forma a compor o que o escritor chamou de ritmo, isto é, a marca do seu próprio estilo literário. ${ }^{6}$

A fim de abordar o que foi exposto, estruturei o texto em duas grandes partes. $\mathrm{Na}$ primeira são analisados, sempre que possível em fontes primárias, os universos teórico e crítico onde se situam as Canções. Em seguida, e precedendo algumas considerações finais, é analisada a segunda parte do livro, intitulada Amar. Nesse segundo momento, o intuito é compreender tanto a técnica da circularidade interna quanto a sua finalidade em transmitir uma mensagem essencialmente filosófica (caracterizada pela alusão, a ironia, a sátira e a alegoria). Devo ressaltar, por fim, que este texto não tem por finalidade (e nem teria como) tornar Raul Pompeia um filósofo, no sentido usual do termo, mas tão somente apreender a sua filosofia literária. Trata-se, portanto, de um estudo que visa colocar em prática os pressupostos teóricos acerca da relação entre Literatura e Filosofia tomando como base o caso de Raul Pompeia.

5 É o que atesta a análise da crítica. Para citar apenas um exemplo, mesmo o recente trabalho de Silva (2020), que possui o mérito de efetuar uma análise da edição original das Canções, também concluiu pelo pessimismo de Pompeia: "As Canções são marcadas por um malogrado esforço do autor em decodificar o segredo do universo, origem de seu pessimismo e escárnio à pequenez e impotência próprias da condição humana." (2020, p. 28). Como pretendo demonstrar ao longo do texto, Pompeia empreendeu sua desmistificação dos mistérios da Natureza de forma consciente, sabendo que tal tarefa dificilmente será levada a termo pelo gênio humano. Acredito também que Pompeia não nutria um escárnio, sentimento no mínimo pungente. É verdade que tinha uma visão negativa da natureza humana, mas se tivesse escárnio não faria sentido defender como defendeu o ideal da Arte, aqui entendido como uma possibilidade de redenção da Humanidade.

6 Assim como a dimensão sociológica das Canções sem metro, o estilo sutil, fundamentado no ideal de ritmo eloquente, constitui uma outra faceta da obra de Pompeia. 


\section{Onde situar as Canções sem metro?}

Raul Pompeia foi um escritor vanguardista. Ao transitar por correntes literárias distintas (realismo, simbolismo, romantismo, impressionismo etc.) a fim de produzir suas obras sem ter com elas nenhuma dívida de composição, Pompeia foi o primeiro a introduzir na literatura brasileira o poema em prosa, do qual suas Canções sem metro são o melhor exemplo.? Mas mais do que isso, é possível dizer que Pompeia deu a esse gênero o que se poderia chamar de "um toque pessoal”: acrescentou as técnicas do chiaroscuro e da circularidade interna em sua composição.

Por ora, basta que tenhamos em mente o que se entende por esse último conceito, a fim de que o exemplo dado oportunamente sobre o chiaroscuro possa se fazer compreendido e complementar. Se a referida técnica não lhe é exclusiva, não se pode dizer o mesmo da forma como Pompeia a empregou, o que lhe possibilitou elaborar uma escrita literária passível de uma leitura filosófica. A técnica consiste em uma tríade circular que se faz presente primeiro em cada canção (apresentação do tema, desenvolvimento e conclusão); depois, pela temática circular que as interliga, como é o caso das estações do ano, o que justifica, como prova de sua circularidade, o título da seção analisada na segunda parte do artigo (Amar); por fim, o conjunto formado por todas as seções compõe a circularidade geral da obra, permitindo assim uma leitura holística de fundo filosófico-moral. Pompeia visava, com isso, transmitir implicitamente uma mensagem filosófica, mas também política, social e cultural de forma concisa, sem que fosse preciso abrir mão da sutileza que o caracterizava.

Eloy Pontes (I934, p. I90) disse, embora com relação a O Ateneu, que a "delicadeza de sons é o segredo desse estilo" que o escritor soube imprimir às suas obras. Não por acaso, logo na primeira canção do livro, intitulada Vibrações, podemos encontrar a prova real dessa "delicadeza de sons": segundo Pompeia, é necessário "vibrar, viver", do que decorre a "sonoridade, colorido: eis o sentimento. Daí o simbolismo popular das cores" (I900, p. 9). Um dos primeiros críticos a ressaltar o vanguardismo de Raul Pompeia em suas Canções sem metro foi Araripe Júnior, seu coetâneo e amigo. Segundo ele, em crônica do dia 2I de abril de I894, o "brasileiro, na exuberância incoercível de sua natureza tropical, pode protestar contra o lirismo perdulário, e meter-se no jugo do ritmo e da correção helênica”, ou seja, a própria definição do parnasianismo, mas, embora a possibilidade exista, "não tardará a insurgir-se contra a disciplina e despedaçar os moldes que tiver adotado" (I894, p. 298). E foi justamente o que fez Pompeia. Dado que Araripe Júnior teceu suas reflexões pautando-se no "Retrospectivo literário do ano de I893" (título de suas crônicas), ele pôde comparar as canções de Raul Pompeia com o Missal, de Cruz e Souza (I86I-I898). Porém, cabe salientar que, por essa época, embora os jornais frequentemente anunciassem que

7 Para maiores informações sobre o poema em prosa, ver Kempinska (20I9) e Paixão (20I2), além do já citado Silva (2020). Vale destacar que os dois primeiros autores não fazem qualquer menção à contribuição dada por Paul Pierson (cuja obra Métrica natural da linguagem serviu de prefácio para a primeira edição das Canções), assim como não mencionam nada, apesar da profundidade de suas considerações, sobre os papéis desempenhados por Pompeia e Cruz e Souza na introdução desse gênero no Brasil. 
em breve seria publicada uma compilação de Canções sem metro, ainda não existia tal compilação, ao passo que Missal foi publicado em volume único já em I893.

Ainda de acordo com Araripe Júnior, em crônica de 26 de maio de I894, havia uma "grande diferença" entre a obra de Raul Pompeia e a de Cruz e Souza, que era "determinada desde logo pela raça e pelo temperamento de cada um" (I894, p. 338). A causa dessa diferença era basicamente o fato de que "Raul Pompeia possui a acuidade dos psicólogos da nova geração e um espírito profundamente inclinado à filosofia sugestiva", que deve muito aos ensinamentos de Proudhon e às "tendências tolstoinas para a organização do serviço de salvação da ideia”. Cruz e Souza, contudo, "anda em esfera muito diferente". "De origem africana, como já disse, sem mescla de sangue branco, ou indígena, todas as qualidades de sua raça surgem no poeta em interessante luta com o meio civilizado que é o produto da atividade cerebral de outras raças." Disso resulta que a "primeira sensação desse encontro é a sensação de 'maravilha'. Cruz e Souza é um maravilhado". É claro que uma conclusão como essa está umbilicalmente situada na conjuntura racial do século XIX. Para o que nos interessa aqui, mais importante do que mapear as causas que justificariam o julgamento de Araripe Júnior é termos em mente que, mesmo naquele contexto, os críticos souberam distinguir o vanguardismo desse empreendimento literário conhecido como poema em prosa, assim como souberam distinguir as diferenças entre um escritor e outro.

Outro crítico e coetâneo de Raul Pompeia que comungou da opinião de Araripe Júnior foi Pedreira Franco. Para ele, em crônica de I3 de novembro de I888, Raul Pompeia, enquanto "poeta e artista", "compreende as necessidades da época e, conclui, que a poesia pode existir independente da versificação" (I888, p. 22). Ao ressaltar o empreendimento inovador que resultou na concepção de O Ateneu - um "livro de combate e livro de reforma" -, Franco chama a atenção para o seu aspecto vanguardista, dado que esse romance estaria "cheio de inovações ousadas e justas". Ainda nessa mesma página, conclui que Raul Pompeia tem uma "individualidade" que "não se parece com a de escritor algum", isso porque "o estilo pertence-lhe, é seu, e, em relação à língua, deu-lhe o máximo desenvolvimento que a evolução permite. De Raul Pompeia posso dizer: escreveu poesia em prosa, da mesma sorte que Olavo Bilac escreveu-a em versos." O estilo, como se sabe, é marca do autor de Canções sem metro: "o estilo", diria Raul Pompeia em crônica de 2I de julho de I888, "é a justa proporção do sentimento com a prosódia da frase. Para viver realmente, o estilo depende da leitura idônea, como a composição musical depende da excelência do executante". Embora se trate aqui de estilo literário, não devemos esquecer que são os estilos que permitem aos escritores compor suas obras; daí que a literatura seja sempre, conforme asseverou Higino (20II, p. 73), uma "invenção", algo que é "produzido, fabricado, por um determinado escritor, dentro duma determinada cultura, num determinado momento histórico", tal como também o é para o filósofo, uma vez que essas “invenções não são mais do que um 'dar-se conta' de potencialidades que estão aí no já dado pela natureza”.

A compreensão de Pedreira Franco está em plena sintonia com a noção que o próprio Raul Pompeia expressou, logo nas primeiras canções (Vibrações). Basta observar o que afirma o crítico: "de todas as modalidades da Arte, a poesia é a mais 
ampla; invade os domínios da música, da pintura e da plástica”, razão pela qual “as vibrações sonoras, subordinadas ao ritmo, à versificação e ao acento, falam ao ouvido por combinações musicais", assim como as "descrições e as pinturas reproduzindo, por sua vez, também, as vibrações luminosas, afetam a retina despertando a sensação das cores e das formas", de "sorte que o poeta é, ao mesmo tempo, músico, pintor, escultor e arquiteto. Raul Pompeia e Olavo Bilac estão neste caso" (FRANCO, I888, p. 23). Como podemos perceber, o amálgama formado pela mistura de cores e fonemas, tal como aludido pelo crítico, fato também percebido por Marciano Silva (2002, 2003) e Gustavo Silva (2020), constitui a própria definição de Canções sem metro.

Sobre esse aspecto da composição literária de Pompeia, quem nos fornece alguns subsídios importantes para uma melhor compreensão é seu amigo Domício da Gama. Segundo ele, em crônica de 25 de julho de 1900 - trata-se de uma reprodução do discurso que proferiu na Academia Brasileira de Letras -, o "poeta-pensador Raul Pompeia descia sempre ao que julgava ser os fundamentos inabaláveis da ciência", para só então compor suas obras. "Um dia encontrei-o que estudava a teoria das vibrações. 'Neste estudo encontro eu toda a estética e a própria vida', explicava ele, 'porque a arte reproduz as vibrações, e vibrar é viver'”. Pautado ou não pela ciência, uma coisa é fato: que Raul Pompeia estudava seus temas antes de sobre eles dissertar, suas próprias crônicas o comprovam. Domício da Gama, na crônica publicada no dia seguinte (26/7/1900), menciona ainda: "pelo livro todo das 'Canções' as notas dominantes são as graves, de vibração profunda, como assenta à música do pensamento de que a alma humana é o tema". Essa "vibração profunda" teria sua origem, segundo ele, no fato de que Raul Pompeia "era torturado pela curiosidade ardente de conhecer o outro lado, o interior, a alma das coisas".

É devido a essa característica que se faz também necessário abordar um tema um tanto polêmico, qual seja: o suposto pessimismo de Raul Pompeia. Embora "sua complicação psicológica” fosse "toda de aparência”, segundo Domício da Gama (25/7/1900), Pompeia "não sentia que a paga do amor é o próprio amor", e, como um "novo Pigmaleão criador da beleza em sonho", queria ele "receber da fugitiva bondade, da precária justiça, da incerta humanidade a volta do seu ardente culto, remédio às suas ânsias de paixão". Disso não poderia resultar senão uma espécie de desilusão, uma vez que o plano ideal, idealizado por Pompeia, não era passível de concretude no contexto social, político e cultural de sua época (só dela?). Seria então essa impossibilidade de viver segundo o seu ideal que imprimira "às suas melhores páginas de contemplação a tinta escura do pessimismo, que era o fundo na sua filosofia. Não do pessimismo que nega o progresso, mas do que se queixa dos sofrimentos da jornada" (Ibidem). É fato que o próprio Pompeia escreveu, em sua canção intitulada A Arte (I900, p. 49), que a realidade é um "círculo de trevas" e que "esquecê-la é consolar-se", o que não se trata de uma simples negação, mas sim de uma visão que ressalta a importância de se ter um ideal para melhor se organizar e viver entremeio à realidade cotidiana (nesse caso, o ideal é a Arte). A interpretação de Domício da Gama, que ressalta não a esperança, mas antes o pessimismo, estaria fundamentada no fato de que "desde Frutos verdes este gemido se exala de não ver cumpridas as promessas da Esperança”.

Quanto à questão da "paga do amor", podemos dizer que ela constitui o próprio 
tema da segunda parte de Canções sem metro, cujo sugestivo título é Amar. Nela, como veremos a seguir, o amor é descrito de duas formas: explicitamente, como uma relação de exploração e dominação sensual e sexual, e implicitamente, ou melhor, filosoficamente, de acordo com a concepção que tinha Pompeia acerca da natureza humana. A alegoria com as estações do ano, não por acaso, simboliza, em ambos os casos, a inevitabilidade do ciclo vital; é dessa forma que o escritor aponta para a esperança sempre despertada e reforçada a cada novo ciclo (nascimento e primavera tornam-se então sinônimos). Pompeia, entretanto, propõe essa reflexão não sem antes aludir ao aspecto sombrio da natureza humana (fator ingênito), a fim de, com isso, ressaltar o quanto esse reiniciar de cada ciclo não só comporta como emite e permite a "esperança da corrigenda", isto é, a possibilidade da constituição de uma sociedade melhor, de uma "existência mais conforme com a relatividade agridoce, que éa partilha comum do ser", conforme se expressou em relação a Max Nordau, em crônica de 6 de agosto de I888. Esse trecho, aliás, não é uma mera citação, é uma filosofia de vida: como notou Braga-Pinto (20I4b), a maior e mais penetrante influência exercida por outro escritor sobre Pompeia deve ser buscada não em escritores como Charles Baudelaire, Émile Zola ou Victor Hugo, dos quais, evidentemente, não se pode negar a influência, mas sim em Nordau. ${ }^{8}$ Eis a fonte do pessimismo de "fundo" aludido por Gama.

Embora concorde com ele quando afirma, acertadamente, que Raul Pompeia não era contra o progresso, mas sim que se questionava quanto aos seus rumos, benefícios e malefícios - daí a "queixa dos sofrimentos da jornada" -, discordo de sua opinião em relação aos "gemidos" de promessas não cumpridas, presentes desde a canção Frutos verdes. Aliás, a análise dessa canção é duplamente importante, já que nos permite apreender, junto com o pensamento de Gama, o suposto pessimismo de Pompeia e, com ele, retomarmos, via exemplo, a técnica do chiaroscuro. Frutos verdes apresenta a mesma tonalidade de canções como A bandeira branca, Hebe imortal e $O$ ramo da esperança, sem deixar de aludir ao tema desenvolvido em Vibrações e Amar. 9 Ainda que predomine um cenário lúgubre e triste - impressão realçada pelo emprego de adjetivos como "velhas", "amargura”, "sonâmbulas”, “ásperos”, “dolorosa”, “baixo”, "horrível”, "tortura”, "gangrena”, "triste" -, a canção é um convite à esperança, tomada enquanto ideal, por dias melhores (ao contrário da interpretação de "promessas não cumpridas"). Vejamos o seguinte trecho:

Sentiam-se as cidades, ao longe, na penumbra murmurante, ouriçadas de torres e minaretes. E de longe, com a viração, como um eco distante, chegavam destroços de mil rumores humanos - a voz de todos os desgraçados, dos cegos sem sol, dos famintos sem trigo, dos suaves sem carinho, dos humildes sem amparo, dos altivos sem triunfo, dos triunfantes atraiçoados, dos traidores em agonia de remorso, todas as escalas do gemido e do desalento. As confissões do coração humano diziam entretanto: Esperança! (POMPEIA, I895, p. I9).

8 A influência de Nordau sobre Pompeia foi reconhecida com propriedade, até onde os achados me permitem afirmar, apenas por Braga-Pinto (20I4b) e Silva (2003). Mesmo Miskolci e Balieiro (20II) ao estudarem $O$ Ateneu, ou Silva (2020) em sua recente análise holística das Canções, não fizeram qualquer menção a Nordau.

9 É importante que se diga que nenhuma dessas canções figura na edição de I9oo, embora façam parte de edição de 2013 . 
Após a descrição de um inferno dantesco que em tudo contribuiria para a interpretação de Domício da Gama, desde que, e somente se, a canção terminasse em "escalas do gemido e do desalento", Pompeia apresenta a solução: Esperança. Essa mesma esperança origina-se não do acaso, mas simbolicamente do próprio "coração humano", ou seja, do mesmo humano que compõe aquele cenário caótico e destrutivo, demonstrando com isso a possibilidade de sua redenção. Mas, com efeito, a canção não termina dessa forma, e sim da seguinte: "Esperança! esperança! Vésperas verdes primaverais, confiantes do outono certo, eternas vésperas venturosas da ventura! Mas eu não vi na terra um único pássaro, que se nutrisse dos acres frutos verdes... prometedores". Creio que essas últimas palavras são fundamentais para interpretar o que queria dizer o escritor. Vejamos a alegoria com as estações do ano, tal como em Amar: o verde primaveril é a própria expressão simbólica dessa esperança, que é, aliás, tanto um ideal quanto um motivo literário. Com isso, Raul Pompeia visa transmitir não a noção de que se deve perder a esperança - por mais certo que seja o fim do ciclo ou por pior que seja o contexto -, mas antes a de que, embora tal sentimento não erradique os riscos, possibilita, contudo, a confiança e a determinação (eis o significado do jogo de palavras "venturosas da ventura"). $E$ na derradeira frase que o escritor condensa seu ideal: nunca viu nenhum pássaro, diz ele, que se alimentasse de um fruto verde. Ora, e como poderia? Afinal, se ele não se alimenta, é justamente porque o fruto ainda está verde (dimensão temporal); eis o porquê do termo "prometedores": além de ser a própria síntese da primavera, esses frutos, quando maduros (outono), servirão de alimento. É assim que Pompeia retoma o ideal da esperança, já duplamente reforçado: primeiro, pelo próprio ato de alimentar-se do fruto maduro; e, em seguida, porque biologicamente é a alimentação que permite a continuidade da vida. $E$, portanto, a noção de dimensão temporal que permite decodificar a mensagem.

De fato, a análise dessa canção é necessária porquanto possibilita contrastar a opinião de Domício da Gama e evidenciar que muitas interpretações, mesmo as dos coetâneos do escritor, contribuíram para a constituição de uma imagem bastante pessimista de Raul Pompeia (particularmente ressaltada nos necrológios). Certamente teve alguma influência a opinião que Domício da Gama expressou em crônica publicada no dia 26 de julho de I900, em que afirmou que se "em outro poeta se levaria à conta de extrema mocidade este lirismo sombrio e tumultuoso", em "Raul Pompeia, porém, o estilo é característico e tão bem se poderia dizer que nele havia de durar sempre a mocidade", caso fosse "própria da mocidade sentir vivamente e exprimir sentimentos com intensidade proporcional à sensação". ${ }^{\text {Io }}$ Não obstante a opinião de Gama, o próprio Pompeia, novamente contrariando a crítica,

Io É possível que Domício da Gama tenha fundamentado seu juízo em duas reflexões: de um lado, no fato de que Raul Pompeia foi consagrado no campo literário por meio de um romance ( $\mathrm{A}$ Ateneu), rico em comicidade, que discorre sobre a vida escolar de jovens estudantes internos; de outro, na afirmação bastante conhecida de Capistrano de Abreu que, em crônica de 29 de março de I882, vaticinava o seguinte: "Em minha opinião, Aluísio de Azevedo e Raul Pompeia serão os dois maiores romancistas da nova geração. [...] Mas Pompeia é e ficará sempre um pouco menino. Aluísio foi e será sempre um homem. Portanto, ao passo que este se atirará ao romance social e propagandista, aquele abicará ao romance estético e parnasiano”. 
descreveu em tom zombeteiro a melancolia e a tristeza das classes literárias de sua época, especialmente daquelas compostas pelos estratos mais jovens. Segundo ele, em crônica de 28 de abril de I889, as "classes literárias", de "pretenciosas ambições", seriam "expressamente melancólicas", o que explicaria porque a "mocidade letrada acha gosto em ser triste e passar por triste”, razão pela qual "arranja, logo que pode, uma miopia às pressas, que desculpa os óculos precoces, o grave apêndice de senilidade e aros de tartaruga que lhes garante um bom acolhimento entre os velhos..." “Que querem?", questiona o escritor, no que ele mesmo responde: "precisam ser sisudos. Amanhã, podem todos vir a ser políticos, mestres e guias da vida social. Precisam ir disciplinando o físico da profissão."

Justiça lhe seja feita, Domício da Gama percebeu algo que os outros críticos ou não perceberam ou não destacaram, e que de certa forma está em vivo contraste com as suas próprias interpretações: para ele, Pompeia empregou na sua composição literária a técnica do claro-escuro, isto é, do chiaroscuro. Retomamos assim a definição mencionada anteriormente. De fato, em meio àquele cenário de escuridão descrito em Frutos verdes, o que é que mais se sobressai senão a esperança? Pensemos, com Bachelard (1989), em uma vela acesa em meio a um quarto escuro: o que se sobressai, a luz ou a escuridão? A técnica empregada por Pompeia consiste, como na pintura de Caravaggio, em utilizar a sombra (ou o sombrio) para destacar, pela intensidade do contraste, a luz, também ela um sinônimo para a esperança. Não deixa de ser curioso, entretanto, que Gama aponte tal técnica e se esqueça de aplicá-la à sua própria interpretação, conforme atesta a concepção das "promessas não cumpridas" (em consequência do simples esquecimento temporal de que a esperança não é sinônimo de concretude).

A interpretação que tende a destacar o vanguardismo de Pompeia, seguida de uma menção ao seu suposto pessimismo, não constitui um particularismo de Domício da Gama, pois ela também pode ser encontrada em Araripe Júnior, um dos primeiros críticos de $O$ Ateneu. Ao examinar o romance, em crônica de II de dezembro de I888, Araripe concluiu que é possível "classificá-lo como o produto de uma imaginação de artista valente, ávido de originalidade, exaltado pela reflexão, contido pelo escrúpulo e pela consciência de sua arte", ou seja, como um vanguardista. Com relação aos aspectos pessimistas e sombrios presentes em algumas correntes literárias da época - não aqueles atribuídos a Raul Pompeia, mas sim os que caracterizavam a literatura decadentista e simbolista -, Araripe Júnior lhes direciona cáusticas críticas, acusando tais manifestações de serem frutos do "desequilíbrio entre a aspiração e o poder de execução", isto é, presunçosas e pernósticas, razão pela qual recairiam em um "fundo comum" de onde tem saído "todas as manifestações de pessimismo até hoje conhecidas". Para o crítico, ainda nessa mesma crônica, foi "daí que recentemente interrompeu a escola simbolista", chamada por ele de uma "nova forma do eufemismo, que se traduz agora por um niilismo literário inominado".

É interessante mencionar essas considerações a fim de ressaltar a sua contradição enquanto crítico literário, o que se torna evidente quando Araripe Júnior diz explicitamente que tem "negado mais de uma vez que o pessimismo seja a característica do século XIX”, embora não deixe de demonstrar receio e temor com relação a esse "inominado" que diz não existir: "seja como for, esse pessimismo de 
conserva e de vitrine, se é que existe" - vide a hesitação ao reconhecer sua existência -, "não passa de um acidente mínimo, no movimento ascendente da humanidade, percebido por muito poucos" e "perdido no meio do entusiasmo do exército que marcha cheio da própria força, mal comparado ao espírito do sistema que reina nas obras clássicas de Schopenhauer, Hartmann e Max Nordau”. Essa última consideração de Araripe Júnior nos possibilita uma melhor compreensão de Canções sem metro: ora, como Raul Pompeia foi fortemente influenciado por Nordau, e como este já possuía certa fama, justificada ou não, de ser pessimista, possivelmente decorra daí muito do pessimismo atribuído a Pompeia. É claro que em alguma medida alguns traços de sua personalidade podem ter contribuído para essa interpretação, no entanto, a julgar pelo que escreveu, Pompeia não se via como pessimista. É o que se pode concluir a partir da crônica publicada em 8 de junho de I889, quando categoricamente afirma que "não molho a pena no canto do olho, para colher uma lágrima de pessimismo; porque, além do risco de furar o olho, garanto-lhes que traria a pena seca."I

Observe-se a lógica argumentativa de Araripe Júnior: ele tece duras críticas ao pessimismo e às literaturas que o empregam, acusando que sua origem está nas influências exercidas por certos escritores. No entanto, em crônica do dia I2 de dezembro de I888, Araripe deixa evidente o seu receio de que Raul Pompeia enveredasse pelos caminhos do simbolismo e do decadentismo (chamado por ele de “decadismo"). Em sua concepção, mais especificamente no que se refere às Canções sem metro - não esqueçamos que estamos ainda no ano de I888 -, Raul Pompeia teria tentado "guindar-se a essas inacessíveis regiões da poesia rosiclér", contudo, "sua índole, porém, não era a de um verdadeiro parnasiano”. O parnasianismo, como se sabe, prima pelo rigor da metrificação, e como Pompeia possuía um "espírito investigador, muito amigo do observar, e muito agudo, era-lhe impossível embotar-se nessa clarividência sempiterna da musa grega, transportada e aquecida ao sol das concepções modernas”.

O receio de Araripe Júnior é compreensível. Em crônica do dia I5 de dezembro do mesmo ano, na qual defende que os simbolistas são "perturbados pelas teorias Helmotz, Meyer e Pierson”, sugere o crítico, como que por extensão, que Pompeia estaria também perturbado por essa "psicologia da voz" e da "métrica da linguagem", ambas sendo responsáveis por "uma exagerada aplicação à literatura do princípio da contiguidade das sensações obtidas pelos diversos sentidos”, conforme se referiu com relação às influências exercidas pela tríade autoral sobre os simbolistas e os decadentistas. Estamos, portanto, frente a uma contradição. Por um lado, Araripe Júnior elogia Pompeia e tenta não classificá-lo como um decadentista ou simbolista; por outro, tece duras críticas a esses movimentos, citando inclusive escritores e filósofos dos quais sabia que Pompeia era leitor, do que decorre que, pelo menos indiretamente, Araripe Júnior também o julgava como um membro de tais correntes literárias, embora não o criticasse diretamente (talvez movido por sua amizade), daí a sugestiva noção superior de receio.

Mas, segue o crítico em crônica de I8 de dezembro de I888, se o "temperamento de Raul Pompeia achou na teoria da instrumentação literária largo campo para

II O que demonstra que Raul Pompeia conheceu e rechaçou, ainda em vida, a pecha de escritor pessimista. 
desenvolver-se", não teria sido essa mesma “instrumentação" a principal responsável pelo fato de que Pompeia tornara-se o vanguardista do gênero poema em prosa no Brasil? Cônscio de que teria de pagar um alto preço pela possibilidade do elogio, Araripe Júnior se contradiz em suas próprias críticas quanto às "influências negativas" exercidas pelos simbolistas sobre Raul Pompeia, o que fica evidente quando afirma, na referida crônica, que o sentimento que "fala a linguagem não se fragmenta por vocábulos, como nos dicionários. É a emissão de um som prolongado, o crepitar de consoantes alteando-se ou baixando, conforme o timbre vocal" (grifos do autor). Tal interpretação é a própria definição de Canções sem metro, explicitada, como visto, desde Vibrações ("vibrar, viver"). Com isso, o crítico e amigo de Pompeia vê-se obrigado a declarar o vanguardismo desse último: "Raul Pompeia leu a Métrica natural da linguagem de Pierson e esse livro abriu-lhe aos olhos regiões inexploradas". Ora, se o autor de O Ateneu enveredou então pelo caminho dos simbolistas - desprezados por Araripe Júnior -, cabia ao crítico efetuar uma ressalva, sem dúvida necessária depois de suas críticas: "Eu acredito que Raul Pompeia seja capaz de perder o bom senso, entrando pelo terreno das abstrações científicas; mas julgo-o impenetrável à fraqueza do misticismo clássico", o que equivale a dizer algo como "ele é uma boa pessoa, apesar das más influências".

Ao definir Pompeia como "realista subjetivista", em crônica de 20 de dezembro de I888, e alegando que a "música e o colorido são dons naturais" do escritor, podemos perceber como até mesmo Araripe Júnior, crítico do simbolismo e do decadentismo, concebia a composição de Canções sem metro como algo original, quase natural. É por isso que a mistura de crítica com elogio recai na necessidade da ressalva: se "os decadentes, os místicos, os sonâmbulos literários, associam cores, sons, aspectos vagos, isolando-se completamente do ambiente", Raul Pompeia, por sua vez, "apenas segrega-se das sensações de conjunto; eis porque ele não é um realista objetivista”. Chegamos aqui a um ponto que nos é particularmente importante, pois remete àquilo que Higino chamou de "paixão inventiva", e que já foi ressaltado por, pelo menos, dois contemporâneos de Pompeia (Araripe Júnior e Rodrigo Octávio), ou seja, o aspecto simbólico, subjetivo e filosófico de suas obras em geral, e de Canções sem metro, em particular - fato que lembra Derrida, para quem a "literatura pressupõe que seja dada licença ao escritor para dizer tudo o que queira ou tudo o que possa", desde que "protegido de toda censura, seja religiosa ou política" (20I4, p. 52).

Se além de artista e escritor, Raul Pompeia foi também filósofo e pensador, conforme disse Araripe Júnior na já citada crônica de I2 de dezembro de I888, cabe igualmente salientar que, de acordo com o crítico, os seus escritos seriam perpassados por uma filosofia moralista, dado que Pompeia era "obcecado pela moral", conforme alegou em crônica de 3I de dezembro de I888. Mantendo-se a complementaridade entre Filosofia e Literatura, podemos citar também Rodrigo Octávio (I896, p. I08), segundo o qual "em Raul Pompeia o filósofo e o escritor se completam e se integram". Para Octávio, o filósofo veria "as coisas e os homens de um modo original, através de sua tristeza e de sua idiossincrasia", ao passo que o escritor "vestiria" as "observações do filósofo de uma roupagem surpreendente de brilho e frescura, obtida por um trabalho cuidadoso e consciente, em que punha toda atividade, toda a arte, todo o talento". Tal assertiva parece definir todo o projeto que resultou nas Canções sem 
metro. De acordo com Octávio (I896, p. I06), muito da filosofia de Pompeia é devida à sua formação circunspecta e autodidata: "desde muito criança, afeito ao estudo e à meditação, viveu consigo só, graças a uma educação quase monástica, em que a sociedade, a vida ruidosa e fácil dos salões, não entrou”; aliás, decorre desse seu caráter reservado o fato de que "raros penetraram no seu gabinete de trabalho e conheceram os segredos de sua existência de artista”. Embora o autor destaque que Pompeia "era alegre, entusiasta, turbulento mesmo nas expansões de sua alegria e do seu entusiasmo", não deixa de chamar a atenção para o seu "isolamento", no qual "trabalhava com um ardor de crente, com uma sinceridade de convertido". Octávio, ainda na mesma página, atribui justamente a este "esforço contínuo e fatigante" a origem da "exaltação perene em que vivia e que lhe preparava o espírito para ver em todas as coisas, as mais naturais, uma segunda intenção, pérfida, insidiosa, ameaçadora". ${ }^{\text {I2 }}$

Como podemos perceber, são visões distintas e às vezes conflitantes sobre um mesmo e único objeto que imprimem a Raul Pompeia sua marca distintiva. Por exemplo, na canção Verão, como veremos a seguir, a descrição da cena se dá em, no mínimo, três planos, pois contempla concomitantemente (I) a descrição biológica da defloração sexual, (2) o detalhamento poético e irônico desse processo permeado de "perfídia, insidiosidade e ameaça" e, por fim, (3) a mensagem filosófica da vida que, mesmo em meio às adversidades, mantém seu ciclo e possibilita a "esperança da corrigenda". Podemos retomar aqui os já mencionados receios de Araripe Júnior: apesar de não citar nomes, Rodrigo Octávio (I896, p. I07) diz, com relação a Raul Pompeia, que a "misantropia instintiva do seu temperamento" foi "formada pela educação e cultivada pelo convívio assíduo dos filósofos e dos poetas doentios que encaram a vida somente pelo prisma da sua inocuidade dolorosa e desconsoladora", algo, como visto, muito próximo da concepção já notada por Domício Gama quando se refere aos "sofrimentos da jornada”. Embora os críticos coetâneos de Raul Pompeia tendam a destacar o viés pessimista, sombrio e mesmo doentio das influências exercidas e absorvidas por ele, todos são unânimes ao ressaltar, ainda que distintamente (às vezes sem compreendê-lo), o caráter filosófico de suas obras.

I2 Quem nos dá uma boa prova de que Raul Pompeia tinha, desde jovem, um caráter sério, grave e circunspecto (o que não quer dizer sombrio e pessimista) é Capistrano de Abreu. Na sua já mencionada crônica de 29 de março de I882, diz ele que "além de correcionalmente trágico, Pompeia é refratário ao cômico. Já lhe viram alguma página espirituosa? Sabem algum dito engraçado seu? Lembram-se de alguma gargalhada sua, franca e gostosa? Por minha parte, respondo: ‘não' a todos os quesitos.” Ainda nessa mesma crônica, ao analisar o ensaio literário intitulado Uma tragédia no Amazonas (uma das primeiras publicações de Pompeia), diz o cronista que o “talento de Pompeia é ultra-trágico. Não há uma só pessoa que não morra na “Tragédia”. Entretanto, e não sem certa ironia, Capistrano alega também que "agora ele contenta-se em mutilar ou desfigurar os personagens. Já é um progresso.” Tudo leva a crer que essa concepção hiperbólica teve certa influência. 


\section{Amar - a alegoria do ciclo vital e a Esperança}

Acredito ser pouco provável, com base no que foi exposto até aqui, que alguém não concorde com Domício da Gama quando afirma, em crônica publicada no dia 29 de julho de I900, que em "tudo o que Pompeia escreveu se encontram análogos, de tonalidade vária e de valor seguro". A segunda parte de Canções sem metro vem ratificar essa afirmativa. Composta por quatro canções, cujos títulos correspondem às estações do ano, e tendo por fim uma quinta canção, intitulada Ilusão renitente, nela fica evidente, mais do que em qualquer outra parte do livro, o emprego da técnica que eu chamo de circularidade interna. Sugestivamente intitulada Amar, essa segunda parte do livro remete à noção de que o amor compreende - e faz-se também necessário, pois representa eufemisticamente a garantia da reprodução sexual - todo o ciclo de uma vida, estando presente desde a juventude primaveril até a decrepitude invernal. Aliás, é com base nesse último tema que o escritor inicia sua primeira canção, intitulada Inverno (estação do ano que representa a morte).

Ao começar sua narrativa precisamente pelo fim do ciclo (Inverno), Pompeia quer com isso sugerir que mesmo um cenário como esse não é capaz de impedir a Esperança do florescimento (Primavera) ou, o que vem a dar no mesmo, o florescer da Esperança. Ao inverter o ciclo vital, comprova-se a potencialidade da vida sobre a morte, da Esperança sobre a desesperança (destaque-se que, das quatro estações, três representam a vida Primavera, Verão e Outono -, e mesmo aquela que representa a morte não é capaz de impedir que um novo ciclo se reinicie, pois ela própria também faz parte de um ciclo natural, logo, irrevogável). Portanto, para melhor explorar essa composição literária e sua filosofia tácita, a análise seguirá o mesmo percurso do original, o que equivale a iniciar pela canção Inverno e findar com a canção Ilusão renitente.

$\mathrm{O}$ contexto artístico e filosófico contido em Inverno, ${ }^{\mathrm{I3}}$ assim como em todas as demais canções, é duplamente interessante, pois pode ser compreendido tanto por seu valor estilístico quanto alegórico. A escolha dos adjetivos utilizados para caracterizar certos substantivos é particularmente elucidativa: "tristes nevoeiros", "frios negrumes", “longa treva”, "perpétua solidão inóspita”, além de frases inteiras: "decepções, obscuridade, solidão, desespero e a hora invisível que passa como o vento, tudo isto é o frio inverno da vida”. No primeiro trecho da canção predomina a Natureza no seu aspecto mais pungente - o que faz da vida tanto mais frágil -, mas essa mesma natureza agreste, que forma "no espírito o luto profundo daquele céu de bruma dos lugares onde a natureza dorme por meses”, também permite a esperança, representada pela "espera do sol avaro que não vem". Quando Pompeia emprega a expressão desoladora de que "nem ao menos a letargia acorda ao clarão de falsas auroras", deixa evidente a alegoria: mesmo com os avanços alcançados no século XIX (eletricidade, telégrafo, vapor), o ser humano continua incapaz de acordar de sua letargia, isto é, permanece na mesma situação que lhe é inerente (exploração, conflitos, pobreza, privação de liberdade), com a única diferença de assumir uma posição relativamente mais confortável do que outrora, o que lembra Magalhães (2009, p. 48) quando afirma que "o pensar filosófico se dá na literatura e a literatura

I3 POMPEIA, Raul, op. cit., Inverno, p. I9-20. 
refrata os grandes debates desenvolvidos na filosofia”, assim como na política e na sociedade na época do escritor.

É a "falsa aurora", sugestivamente empregada como sinônimo de algo capaz de iludir, que faz com que procuremos "encontrar fora de nós alguma coisa do que nos falta”, sugerindo com isso a busca por um ideal. Em suas canções, Pompeia cita apenas dois exemplos de ideais: a religião e a Arte, sendo esta "sem máculas". A importância do ideal na filosofia de Pompeia se deve ao fato de que ele serve como inspiração (Esperança), ou seja, embora a vida seja limitada, o ideal, especialmente o da Arte, seria imortal. Daí que aqueles "pobres olhos cansados" que "não vão além dos cabelos brancos que caem pela fronte" representem nada menos que o final de um ciclo pela velhice, mas igual e ambiguamente também que os novos ciclos podem seguir sua jornada com base no legado deixado pelos ciclos anteriores (fator cumulativo). Mesmo o "desengano do invernado" não impede a memória, no seu sentido etimológico de lembrar, recordar e, por consequência, dar vida (Esperança), o que fica visível ao rememorar "a seara loura dos bons dias", ainda que "por entre as franjas de neve que os tetos babam ao frio". Embora no Inverno seja "tudo sombrio e triste" (características associadas, por analogia, à morte), bem como é "triste o derradeiro consolo do inverno que embriaga entretanto como o último vinho dos condenados", há ainda assim a reconfortante "recordação dos dias idos, a acerba saudade da primavera”. A “saudade da primavera” é o ponto culminante, pois reconhece a possibilidade de que ela continue a existir independentemente da morte humana (a Natureza supera o Homem).

Ao contrário da canção anterior, em Primavera $^{\mathrm{I} 4}$ há uma personagem com nome definido, chamada Hermínia (corruptela feminina do nome Hermes, que, na mitologia, era o mensageiro dos deuses, significando, por alusão, uma mulher forte, ágil, robusta). Ainda que apresente um tema diverso em relação à canção anterior (liberdade/escravidão), percebe-se igualmente a existência de um raciocínio circular - introdução-desenvolvimento-conclusão -, pautado, sobretudo, pela Esperança. Hermínia, que já na primeira frase tem explícito seu sentimento de remorso, representa a pura ambiguidade, pois rouba um pássaro de sua senhora (daí o remorso) para devolvê-lo à natureza, isto é, à liberdade (segundo a dialética das boas e más ações). Os adjetivos empregados aqui assumem uma outra coloração em vista de seu objetivo final: o contraste.

O canário solto é "absorvido pela vasta alegria bonançosa do azul” de um ambiente em que reinava uma "franca liberdade das brisas", na qual em "cada flor brincava livremente um perfume" que subia ao céu, onde "no alto, muito em cima, voavam as nuvens dispersas como um bando de águias indomáveis” (águias, voar, alto, indomáveis, tal é o sentimento de liberdade enquanto ideal). Essa mesma liberdade, idealmente representada, é transportada para um plano real, alegoricamente terreno (ou seja, algo concreto, possível, plausível): “embaixo, no campo, as próprias árvores, servas da gleba, presas pela contingência da seiva, açoutavam-se mutuamente, arremessavam-se punhados de flores, em doida alegria, no gozo da relativa liberdade". E não só essas, mas também seres inanimados adjetivados de forma a ressaltar ainda

I4 Pompeia, Raul, op. cit., Primavera, p. 20-2I. 
mais a possibilidade terrena de liberdade: "as próprias rochas, símbolo da passividade necessária, engastadas no solo, as altivas rochas, realizavam a liberdade onipotente da inércia esmagando Sísifo invisível". E, como não podia ser diferente, "sobre todo este concerto de liberdade, dominava apenas a festiva soberania da Primavera”, isto é, a supremacia da Natureza, que é, em essência, superior ao domínio e à exploração humana. Note-se que a mesma estação que simboliza o início do ciclo vital também simboliza, não por acaso, os ideais de Esperança e Liberdade: acima de qualquer coisa, o que se pretende a partir da atitude de Hermínia é demonstrar que as ações predominantemente boas (os pequenos progressos contidos no decorrer histórico) são possíveis, ou seja, "prometedores".

Será que Hermínia “fizera bem? Fizera mal?” Fizera bem, sem dúvida: “Ah! não era crime, não!", afinal, seu objetivo foi o de "restituir o canário à natureza que o produzira livre, livre como os perfumes, como as folhas secas e as pétalas soltas, livre como a nuvem, livre para voar, cantar, como são livres as árvores para florescer, as rochas para esmagar!” É assim que Pompeia manifesta seu ideal artístico-filosófico, pois ao proporcionar tal reflexão, subsidia-se também a discussão de um problema político seriamente debatido à época, ou seja, a escravidão: esquecia Hermínia "que também lhe era vedado o gozo das primaveras; havia também um céu que em vão a chamava, havia um mundo de expansões que lhe reclamavam a alma ardente de donzela", justo ela, que era capaz de dar liberdade ao pássaro, mas era incapaz de usufruir da sua própria liberdade, pois era escrava. Há também uma outra interpretação: a mesma Hermínia, pelo fato de ter vedada sua liberdade, poderia agir de forma indiferente com relação ao pássaro, deixando-o preso; mas não, contrariando a mesma natureza humana que lhe aprisionara, que lhe é opressiva e faz sentir remorso até mesmo pela prática de uma ação caridosa, ela promove, ainda assim, uma boa ação (Esperança).

O receio da personagem parece ser fruto da sua precária condição, dado que entre as "expansões primaverais e o seu espírito" havia o poder e "a vontade dos homens, rude e fria, como uma grade de ferro", razão pela qual "não lhe pertencia a formosura do corpo nem a vida da alma - pobre escrava!" A eloquência sentimental é também um protesto político. Ora, a mesma Hermínia que "andava, tola! a protestar contra a escravidão dos canários" representa duas condições distintas: uma social e a outra, Humana. Dito de outra forma, ela representa em primeiro lugar aqueles que estavam privados de sua liberdade, e que só viriam a conhecê-la formalmente após a abolição da escravatura, em I888; em segundo lugar, Hermínia representa também os pequenos "desvios de conduta", nesse caso, positivos, da natureza humana (é a própria Esperança de cada ciclo que se reinicia). Essa canção, mais do que qualquer outra, demonstra o quanto a natureza humana era tida por Raul Pompeia como essencialmente má, fato que o predispunha antes para a crença na possibilidade de um cataclisma do que para a utopia da salvação, embora não o impossibilitasse de 
crer na "esperança da corrigenda", representada aqui pelas pequenas, mas sempre possíveis, ações desviantes. ${ }^{\text {I5 }}$

É com essa reflexão que chegamos à canção intitulada Verão. ${ }^{16} \mathrm{O}$ "verão é êxtase do fogo", diz o prelúdio da canção, já que é nessa estação que tudo aquilo que fora prometido na primavera se concretiza: "desabrocha francamente a primavera púbere". A jovem se faz mulher: "o esplendor viçoso das formas da juventude aguarda a carícia da asa do estio que aquece e fecunda”, ação caracterizante e caracterizada pelo período, justamente porque é nele que predomina "a festa do amor, a orgia do fogo". Sem dúvida, essa canção é a que contém a alusão mais explícita aos processos biológicos de fecundidade e de reprodução sexual. São diversas as passagens, ressaltadas por voluptuosos adjetivos, a exemplificarem o instinto reprodutivo, luxuriante à beira do irresponsável, e essencialmente feminino: "fulge no abrasado zênite o sol, como um troféu de espadas nuas e a natureza enleada pelas serpentes da lascívia estival”, em que “debate-se à luz, vencida, - bela amante que sucumbe ao amor carnívoro, pungente de um semideus guerreiro, na própria tenda de campanha, bêbado ainda do furor do recontro, excitado pelo cheiro cruento da matança." É fundamental reter aqui a alegoria, uma vez que esses trechos estabelecem os papéis desempenhados tanto pelo macho e pela fêmea, biologicamente, quanto pelo homem e pela mulher, socialmente.

A beleza é feminina; é a amante que é bela, sedutora e atraente. Mas é igualmente ela, a mulher, que sucumbe ao amor carnívoro, bestial, do homem que age brutalmente por instinto, tal como um semideus forte, viril e guerreiro. E onde isso ocorre? Semelhante à prostituição, duplamente mortífera ao corromper tanto a beleza quanto a pureza, o “acasalamento" se dá na tenda do guerreiro. Há aqui uma clara alusão ao universo predominantemente dominado pelos homens, onde as mulheres alegoricamente e de forma ingênita deixam-se dominar pelo macho duplamente excitado: primeiro pelo sexo em si, com suas claras conotações de dimorfismo sexual; segundo, pela satisfação de haver cumprido com êxito o passo a passo de sua espécie, ou seja, o ritual da guerra (vide a alusão, biologicamente reforçada, ao homem hobbesiano).

Como na canção anterior, também aqui a personagem feminina é nomeada: seu nome é Ruth (cujo significado é amiga, companheira, provavelmente em alusão

I5 A forma como Pompeia concebia a natureza humana pode ser vista, em sua plenitude, na canção Os animais (POMPEIA, I900, p. 35-36). Prefaciada por Gênesis I:26, nela o homem é comparado a um anjo que domina a Natureza, retirando dela suas características: "Veio a águia e ofereceu as asas e os estímulos elevados; o leão ofereceu a juba arrogante e a majestade selvagem; o tigre ofereceu as garras e a sede de sangue; o elefante, a força colossal; o símio, a malícia; a raposa, a sagacidade; a serpente, o veneno e as linhas curvas; o cão, a leal vileza; a hiena, os instintos da traição; o asno, a perseverança; o cavalo, o dorso e a celeridade; o avestruz, o poderoso estômago e a cobiça; o bode, a luxúria; o porco, o próprio ventre e a torpeza; o pombo a alvura das penas; o cisne, o derradeiro canto; o pavão, a vaidade; o rato, a rapacidade - perícia prática do instinto." O “Rei apossou-se de tudo. Estava transformado o anjo de argila." A canção termina com a seguinte afirmação: “E a natureza unânime aclamou esse monstro." Embora de uma outra perspectiva, Silva (2020) também destacou a singularidade dessa canção.

I6 POMPEIA, Raul, op. cit., Verão, p. 23. 
ao Livro de Rute, presente no Velho Testamento). Ela, como a fêmea da espécie, é apresentada como a "selvagem" mulher, outrora "meiga e aérea criança, no fundo misterioso do sangue” (tal como uma criança primaveril), mistério esse ressaltado pela imperiosa assertiva: “Amor de verão!" (ou seja, "fogo de palha”). De forma análoga ao próprio ato sexual, simbolizando a perda da pureza infantil inerente à fase de fecundação (defloração), o que realçaria a verdadeira natureza humana, conclui Pompeia a canção: "viver a intensidade mortal da vida, arder, arder e morrer, como o fogo que cresce, cresce e de si mesmo morre, enfermo do seu triunfo". A eloquência literária transforma essa derradeira frase em uma ambiguidade significativamente metafórica: tem-se, no primeiro plano, uma cena explícita de luxúria animalesca e fálica; e, por extensão, uma demonstração de que tanto o homem como a mulher cumprem um papel necessário à reprodução e à sequência ao ciclo vital.

Fertilizado o óvulo, tem-se o zigoto; eis a "moralidade" do Outono. ${ }^{\mathrm{I7}}$ Assim como "levou-as o vento, há muito, as flores virgens da primavera; o noivado do estio passou também”, mas não levou consigo a esperança dessa estação, pois "hoje a natureza dorme num grande descanso prometedor" (é notória a semelhança com Frutos verdes), ainda que "extenuada pela lascívia das manhãs estiadas". É prometedora justamente porque nos "ramos pendem sopesando intumescidos frutos, e os frutos, gordos de seiva e carne, parem no ar como pequeninos ventres, - maternidade sem ventura! a morrer no chão e a nutrir da própria morte a vida das sementes”. São os filhos, os novos frutos que nascem, os próprios responsáveis pela sobrevivência da espécie, mesmo que o seu nascimento acarrete o padecimento de sua genitora (e não do seu genitor - "maternidade sem ventura" -, cujo papel é essencialmente fertilizar). "Na estação dos frutos”, diz Pompeia, "vão passar almas de mães, ao sol dos pomares, oprimindo o seio contra os lábios dos recém-nascidos”, tal é o desalento caracterizado pela responsabilidade materna (a ausência paterna é significativa), visando deixar claro que o seu papel, além de mais sofrido, é também mais essencial do que o dele (o macho-pai) - embora não o dispense, pois também é necessário -, e isso justamente porque ela (a fêmea-mãe) carrega consigo uma nova vida, isto é, alegoricamente, a possibilidade de um novo ciclo que se reinicia: "melancólicas em sua ventura, cismam e olham pálidas o fausto melancólico do outono, que ostenta a vida enérgica dos rebentos na carne morta dos frutos dispersos". É por causa disso que elas são consideradas "almas mortiças de outono, pálidas, mas ingênitas". A palavra "ingênita" é fundamental.

Se o seu desfecho é trágico, é porque ela o tem como um percurso a ser trilhado naturalmente, do qual não há como fugir, pois representa duplamente a própria força da Natureza e da sua natureza. Alegoricamente, o início de um novo ciclo é pago pela morte do ciclo anterior (mas não de sua herança), o qual já cumpriu sua função (afinal, é no "triste e frio inverno" que padecem progenitores). E poderia ser diferente? Antes de responder à indagação, convém apreender o clímax que antecede o desfecho da canção. Em um primeiro momento, Pompeia parece fomentar o suspense ("querem talvez saber para que nasce o inocente grelo matricida do destroço pútrido de um fruto", "querem saber a que voraz conviva aproveita o banquete opíparo do outono"),

I7 Pompeia, Raul, op. Cit., Outono, p. 24-25. 
para em seguida reapresentar o ciclo vital ("flores da primavera, estos fecundos do verão, gérmens benditos do outono, virgindade, formosura, amor, maternidade e depois a mortalha do inverno!"), assertivas que, no seu conjunto, precedem este elucidativo desenlace: "ninguém vos dirá porque renasce do triste inverno a verde primavera...”. Precisamente porque não precisa ser dito, a resposta já foi dada: é o próprio ciclo da vida que recomeça a cada primavera e finda a cada inverno. $\bar{E}$ por isso que não há como ser diferente, pois a Natureza está acima das escolhas, é "ingênita". No entanto, convém notar que se o essencial é imutável, nada impede pelo contrário, estimula - a esperança pelos avanços "prometedores" representados por cada novo ciclo que se inicia.

A perícia no uso dos adjetivos permite a gradação: se o inverno é frio e triste (velho) e a primavera é tépida e livre (criança), o verão não poderia ser senão o "êxtase do fogo" (jovens), êxtase que resulta na futura responsabilidade de nutrir o fruto (adultos com filhos). O entendimento de Silva (2003, p. 202-203) sobre a segunda parte de Canções sem metro aproxima-se, em alguns aspectos, dessa interpretação, porém, difere radicalmente em outros, uma vez que ele carrega os mesmos vícios observados em Domício da Gama, ou seja, tende a ressaltar o pessimismo sobre a Esperança, assim como a escuridão sobre a claridade, segundo uma leitura particular do chiaroscuro. De acordo com sua interpretação, tem-se a "ideia de que o amor degrada-se em volúpia e luxúria, permanecendo puro apenas na inocência da juventude", o que, segundo ele, "encontra respaldo na alegoria da primavera", fato sobre o qual concordamos mutuamente. Por sua vez, porém, quando Silva ressalta que um contexto como esse "levará o homem à busca incessante de novos prazeres e do poder necessário à sua realização, gerando, juntamente com o desejo de nutrição, a guerra e a cisma entre os homens", penso que ele tome os efeitos pelas causas: o que leva o homem ao seu estado belicoso, segundo Pompeia, é a própria natureza humana, pouco importando a existência de fases anteriores ou posteriores (ciclos), daí que a busca desmedida por prazer e dominação seja antes efeito de sua natureza do que causa. Observe-se que se o homem é essencialmente mau, até mesmo sua ausência pode ser assim classificada (como retratado na canção “Outono"). Tal é a reflexão gradativa que precede a última canção de Amar e prepara o clímax da narrativa, isto é, a sua parte mais clara, no duplo sentido do termo, assim como conclui a seção, segundo o princípio da circularidade interna.

A canção Ilusão renitente, ou seja, uma fantasia persistente, é uma narrativa sobre um "estranho sonho" no qual o narrador alega ter visto um "cataclisma inaudito que assaltou a natureza" e aniquilou completamente todo o universo ${ }^{18}$ Tal cataclisma, espécie de releitura bíblica do Dilúvio junto ao Apocalipse, caracteriza-se pela completa anarquia ("desconcertadas as leis do mundo, rota a máscara das cores, desarmadas as perspectivas, reina a definitiva realidade cega do pavor") inerente ao final do ciclo (morte). Disso resulta que o persistente sonho figura como uma espectral ameaça ao sono dos homens, incutindo-lhes medo e desespero, possível alegoria com as religiões que pregam ameaçadoramente seus preceitos, baseadas no medo do desconhecido, isto é, no medo de uma fantasia que persiste pela simples razão de

I8 POMPEIA, Raul, op. cit., Ilusão renitente, p. 26-27. 
ser ela própria alimentada pelos homens. Em meio a esse caos de duração indefinida, segue o narrador: "cessou o tumulto animado das transformações", bem como "o conflito dos átomos foi substituído por uma pacificação profunda”, e, da mesma forma como "o fogo e a água, confundidos no acordo de uma destruição mútua e simultânea, renunciaram ao velho antagonismo de elementos rivais”, também não há mais a "vida dos vermes na entranha do cadáver, não mais a vida dos astros no vácuo; nem há mais astros no céu nem há mais vermes na terra: o demônio do aniquilamento sustou a marcha sideral das esferas!” Em resumo, trata-se de um cenário catastrófico; verdadeiro cataclisma.

$E$ assim que Pompeia dantescamente concebe o modo como "resolveu-se enfim a universal comédia das formas, das superfícies, das ilusões..." Contudo, se voltarmos ao início da canção, perceberemos que tudo isso não passa de um "estranho sonho" no qual, "como um pássaro envolvido inesperadamente no turbilhão da borrasca, vivia, entretanto, o meu sentimento, no meio da consumação geral das coisas", uma verdadeira ilusão renitente. Essa mensagem, portanto, tanto pode ser uma referência ao sonho do narrador anônimo (um Homem comum) como também à descrição da criação do mundo, tal como em Gêneses: "E eu vi, senti nascer das trevas um clarão suavíssimo, semelhante ao luar que vem do céu, rasgando uma por uma as bambolinas pesadas da tempestade". Mas o que era esse clarão? Nada menos do que "a luz de um olhar..." A prova de que "nem tudo perecera!" Por fim, já extasiado, afirma o narrador: "Este simples clarão saciava-me como se fosse a concentração da vida universal roubada aos seres, ou o espírito errante das constelações extintas!" Há aqui, como podemos perceber, uma perfeita correlação entre literariedade, filosofia e as técnicas do chiaroscuro e da circularidade interna.

Quando à hipótese de um cataclisma capaz de pôr fim à Humanidade, trata-se de uma reflexão de menor importância. O seu emprego - retomada novamente na derradeira canção, intitulada Conclusão - versa, em ambas as situações, sobre fins puramente metafísicos, servindo como uma espécie de alerta, ameaça: o ser humano, dada sua natureza, possui uma predisposição que o inclina antes para o cataclisma do que para a utopia da salvação. A releitura bíblica é empregada exatamente nesse sentido: o Dilúvio é passado concreto; o Apocalipse, futuro possível. O aspecto mais significativo dessa canção é a mensagem implícita contida no momento em que o narrador é despertado daquele estranho sonho (confirmação da ilusão do cataclisma). Ora, o que o faz despertar e ter a certeza de que a realidade é mais "prometedora" do que a fantasia, senão a "luz de um olhar"? E mais, o que essa cândida cena amorosa representa senão a importância, para muito além do mero fator reprodutivo, do ato de Amar? Há de se considerar ainda a possibilidade - Esperança - de que surja uma nova vida, gerada a partir dessa união amorosa. Eis a certeza da continuidade do ciclo da vida. Como visto, o que predomina em Amar é o ideal da Esperança; afinal, é por meio dele que Raul Pompeia tanto inicia quanto finaliza a segunda parte de Canções sem metro. Não estaria, portanto, Domício da Gama equivocado quando disse que Pompeia "não sentia que a paga do amor é o próprio amor"? 


\section{Considerações finais}

Vimos que na obra de Pompeia, com especial atenção para suas Canções, há junto da composição literária uma mensagem filosófica que nem sempre foi compreendida, ainda que percebida. A percepção de ambas depende, em certa medida, da decodificação das técnicas composicionais empregadas por Pompeia ao longo de suas canções, que são essencialmente duas: o chiaroscuro e a circularidade interna. Identificá-las e interpretá-las nos permite apreender as canções de uma forma próxima daquela esperada por Pompeia. Negligenciá-las pode ter como consequência recair no truísmo de que Pompeia foi um escritor pessimista. Como espero ter demonstrado, apesar de alguns críticos, citados ao longo do texto, terem conhecido pessoalmente o escritor, eles mesmos não estavam isentos de interpretações contraditórias. Acredito também que essas interpretações, visivelmente realçadas nos primeiros necrológios, constituem a própria essência daquilo que a crítica atual apenas reconstituiu e deu sequência.

Embora Raul Pompeia concebesse a natureza humana como essencialmente má, o que naturalmente a predispõe para o cataclisma (daí o seu emprego em tom ameaçador), ele não exclui, mas antes incentiva, a possibilidade "prometedora" das boas ações. Logo, há em sua obra um viés antes reformista do que revolucionário: levando a análise até suas últimas consequências, basta tomarmos a ideia de revolução como sinônimo de cataclisma para vê-la desautorizada inúmeras vezes ("ilusão", "estranho sonho" etc.). Eis o essencial de sua filosofia, que confere, não às entidades metafísicas, mas ao próprio homem, a capacidade de transformação social. Afinal, se até mesmo o gênio padece, o seu legado - a Arte - permanece para guiar as gerações futuras (os novos ciclos que se iniciam), amalgamando assim, em um mesmo contexto social, tanto os "gênios" quanto os cidadãos comuns. Como disse Magalhães (2009, p. 48), a "relação entre filosofia e literatura não se restringe às formas literárias da filosofia ou à influência desta na literatura", uma vez que há "momentos de verdadeira fusão entre uma e outra e nisto consiste também parte da história de ambas". Parece que Raul Pompeia foi um desses escritores que conseguiu, a seu modo, fundir ambas em um ambicioso, mas compreendido, ideal artístico-filosófico.

SOBRE O AUTOR

MARCONI SEVERO é Doutorando em Ciências Sociais pelo Programa de Pós-Graduação em Ciências Sociais da Universidade Federal de Santa Maria (PPGCS/UFSM).

marconisevero@hotmail.com

https://orcid.org/0000-0002-5374-5183 


\section{REFERÊNCIAS}

ABREU, João Capistrano H. Tipos e tipões. Gazetinha, 29 mar. I882.

ANDRÉA, João. I2 de abril. In: POMPEIA, Raul. Canções sem metro. Rio de Janeiro: Typ. Aldina, I90o.

ARARIPE JÚNIOR, Tristão de A. O Ateneu e o romance psicológico. Novidades, II dez. I888.

ARARIPE JÚNIOR, Tristão de A. O Ateneu e o romance psicológico. Novidades, I2 dez. I888.

ARARIPE JÚNIOR, Tristão de A. O Ateneu e o romance psicológico. Novidades, I5 dez. I888.

ARARIPE JÚNIOR, Tristão de A. O Ateneu e o romance psicológico. Novidades, I8 dez. I888.

ARARIPE JÚNIOR, Tristão de A. O Ateneu e o romance psicológico. Novidades, 20 dez. I888.

ARARIPE JÚNIOR, Tristão de A. O Ateneu e o romance psicológico. Novidades, 3I dez. I888.

ARARIPE JÚNIOR, Tristão de A. Retrospectivo literário de I893. A Semana, v. 5, n. 38, p. 298-299, 2 I abr. I894.

ARARIPE JÚNIOR, Tristão de A. Retrospectivo literário de I893. A Semana, v. 5, n. 43, p. 338-339, 26 mai. I894.

ARAUUJO, Gilberto. Introdução. In: POMPEIA, Raul. Canções sem metro. Organização, introdução e notas de Gilberto Araújo. Campinas/SP: Editora da Unicamp, 2013.

BACHELARD, Gaston. A chama de uma vela. Tradução de Glória C. Lins. Rio de Janeiro: Editora Bertrand Brasil, I989.

BRAGA-PINTO, César. Journalists, capoeiras, and the duel in nineteenth-century Rio de Janeiro. Hispanic American Historical Review, v. 99, n. 4, p. 58I-6I/, nov./dec. 20I4a.

BRAGA-PINTO, César. The Honor of the abolitionist and the shamefulness of slavery.Luso-Brazilian Review, V. 5I, n. 2, p. I70-I99, jul./dec. 20I4b.

EDITORIAL. Gazeta da Tarde, Rio de Janeiro, 26 dez. 1895.

ELOY, O Herói (Arthur Azevedo). Croniqueta. A Estação, I5 jan. I896.

DERRIDA, Jacques. Essa estranha instituição chamada literatura: uma entrevista com Jacques Derrida. Tradução de Marileide D. Esqueda. Belo Horizonte: Editora UFMG, 20I4.

FRANCO, Pedreira. Raul Pompeia e Olavo Bilac. Revista Treze de Maio, Rio de Janeiro, p. 2I-25, I3 nov. I888.

GAGNEBIN, Janne M. Filosofia e literatura. Limiar, v. 3, n. 5, p. 4-I4, jan./jun. 2016.

GAMA, Domício (Pseudônimo de Domício A. Forneiro). Discurso proferido na Academia Brasileira de Letras acerca de Raul Pompeia. A República, 25 jul. 1900.

GAMA, Domício. Discurso proferido na Academia Brasileira de Letras acerca de Raul Pompeia. A República, 26 jul. I900.

GAMA, Domício. Discurso proferido na Academia Brasileira de Letras acerca de Raul Pompeia. A República, 29 jul. I900.

HIGINO, Nuno. Entre filosofia e literatura: responsabilidade infinita. Revista Humanística e Teologia, v. 32, n. 2, p. 67-8I, jul./dez. 2011 .

KEMPINSKA, Olga. "A alegria é una": o poema em prosa e a poética da ironia. Caligrama, v. 24, n. 3, p. I25-I38, set./dez. 20 I9.

ASSIS, Joaquim Machado. A semana. Gazeta de Notícias, 5 ago. I894.

MAGALHÃES, Antonio. Partilhas do saber: diálogos entre filosofia e literatura. Revista Páginas de Filosofia, v. I, n. 2, p. 47-59, jul./dez. 2009.

MISKOLCI, Richard; BALIEIRO, Fernando F. O drama público de Raul Pompeia: Sexualidade e política no Brasil finissecular. Revista Brasileira de Ciências Sociais, v. 26, n. 75, p. 73-88, jan./abr. $20 I I$.

NUNES, Benedito. Poesia e filosofia: uma transa. A Palo Seco, v. 3, n. 3, p. 8-I7, $20 I I$.

OCTÁVIO, Rodrigo. Raul Pompeia (Saudades e Evocações). Revista Brasileira, tomo V, p. IO3-II2, I896.

PAIXÃO, Fernando. Poema em prosa: poética da pequena reflexão. Estudos Avançados, v. 26, n. 76, p. 273286, set./dez. 2012. 
POMPEIA, Raul. A vida na Corte. Diário de Minas, 28 abr. I889.

POMPEIA, Raul. A vida na Corte. Diário de Minas, 8 jun. de I889.

POMPEIA, Raul . Canções sem metro. Rio de Janeiro: Typ. Aldina, I900.

POMPEIA, Raul. Canções sem metro. Organização, introdução e notas de Gilberto Araújo. Campinas/SP: Editora da Unicamp, 2013.

POMPEIA, Raul. Cartas ao Futuro. Gazeta da Tarde, 27 dez. I897.

POMPEIA, Raul. Frutos verdes. A semana. I6 fev. I895.

POMPEIA, Raul . O Ateneu: crônica de saudades. Rio de Janeiro: Tip. Gazeta de Notícias, I888.

POMPEIA, Raul. Pandora: Crítica. Gazeta de Notícias, 2I jul. I888.

POMPEIA, Raul. Pandora: Os “paradoxos” de Max Nordau. Gazeta de Notícias, 06 ago. I888.

PONTES, Eloy. Raul Pompeia, sua vida, seu tempo, sua obra. Revista Brasileira, n. 5, p. I85-I94, dez. I934.

SILVA, Ana Carolina F. Entre a pena e a espada. Literatura e política no governo de Floriano Peixoto: uma análise do jornal O Combate (I892). Cadernos AEL, Campinas/SP, v. 9, n. I6-I7, p. I37-I78, jan./dez. 2002.

SILVA, Gustavo R. F. Viver é vibrar: estética e cosmologia de Raul Pompeia em Canções sem metro. Revista Garrafa, v. I8, n. 52, p. 6-30, abr./jun. 2020.

SILVA, Marciano L. Por uma revisão crítica da obra de Raul Pompeia. Acta Scientiarum, v. 23, p. I09-I20, jan./dez. 200I.

SILVA, Marciano L . A recepção crítica das Canções sem metro, de Raul Pompeia. Acta Scientiarum, v. 24, n. I, p. I3-I8, jan./dez. 2002.

SILVA, Marciano L. Decadência das civilizações e memória dos ideais: a filosofia da história na obra de Raul Pompeia. Acta Scientiarum, v. 25, n. 2, p. 20I-2Io, jul./dez. 2003. 